\title{
Conversion of diesel locomotive engines to operation on natural gas motor fuel
}

\author{
Vitaliy Asabin ${ }^{1}$, Alexey Roslyakov ${ }^{1}$, Leyla Kurmanova $^{1}$ *, Sergey Petukhov ${ }^{1}$, \\ and Maxim Erzamayev ${ }^{2}$ \\ ${ }^{1}$ Samara State Transport University (SSTU), Svoboda Street., 2V, Samara, 443066, Russia \\ ${ }^{2}$ Samara State Agrarian University (SSAU), Uchebnaya Street, 2, Kinel, p.g.t. Ust-Kinelsky, 446442, \\ Russia
}

\begin{abstract}
This research paper contains the results of analysis of a range of variation of the lower heating value of gas during the process of conversion of diesel locomotive engines to operation on natural gas as motor fuel. It was demonstrated in this paper that the range of variation of the lower heating value at the various fields considered in it varied within the limits to $32.4 \%$. A proposal was made to take into consideration the so-termed lower heating value of diesel fuel and natural gas when running diesel locomotive engines on liquid-gas fuel complementary to atmospheric conditions.
\end{abstract}

\section{Rationale of the research and problem statement}

The urgency of conversion of diesel locomotive engines to operation on natural gas motor fuel is dictated by the need to improve the energy efficient and environmental performance indices of diesel locomotive engines and justified in "Energy Strategy of "RZD" JSC Holding for the Period up to 2030", in "Strategy of Innovative Development" and in "Program of Innovative Development for the Period up to 2020 годa", in the State Program of the Government of the Russian Federation "Introduction of Gas-engine Equipment in the Railway Sector" for the period of 2017-2020.

Natural gas is being used in diesel locomotive engines as motor fuel for the following purposes: fuel acquisition cost saving as the price of equivalent amount of gas is significantly (up to 50\%) below the price of diesel fuel; reduction of emissions of pollutants into the atmosphere.

Hence, utilization of available locomotives subject to minor upgrading of power plants enabling use of natural gas as motor fuel is practicable and efficient for justification of operation of diesel locomotive engines on natural gas.

\section{Theory}

Conversion to natural gas motor fuel allows for improvement of haulage capacity of the self-contained locomotives, increment in their time to failure, lowering of diesel fuel

* Corresponding author: leyla_kurmanova@mail.ru 
consumption and reduction of emissions of harmful substances. According to Program of Introduction of Gas-engine Equipment in the Railway Sector, self-contained traction rolling stock running on diesel fuel shall be replaced with locomotives operating on natural gas.

Compared to diesel fuel, thermodynamic and environmental advantages of natural gas motor fuel are attributed to energy and physical parameters of gas fuel. As reported by domestic and foreign sources, while operating diesel engines on natural gas motor fuel values of emissions of toxic agents decrease by 1.5-2.0 times when it comes to hydrocarbon composition and nitrogen oxides. Utilization of gas-and-diesel fuel results in the marked decline of smokiness, gain in performance (by 2-5\%), lifetime extension, prolonged distance run between overhauls and engine oil life (by 20-40\%) [1].

Options of employment of compressed natural gas (CNG) and liquefied natural gas (LNG) are being explored currently. In all cases compressed gas shall be fed to the engine cylinders and thus that gas state in which gas stock is hauled by the locomotive should be selected.

Utilization of natural gas as motor fuel for operation of locomotives offers the possibility of considerable reduction of air emissions of hazardous substances and lowering of fuel operating costs $[2,3]$.

With the aim to solve the problems of substitution of diesel fuel with natural gas as suggested in Energy Strategy of "RZD" JSC, in 2005, «VNIKTI» JSC ("Rolling Stock Research and Technology Institute" JSC) proceeded with the development of GT1-001 line-haul gas turbine locomotive with a capacity of $8300 \mathrm{~kW}$ with the power plant mounted on a gas turbine engine running on liquefied natural gas.

Nevertheless, the major drawback of power plants of gas turbine locomotives is their low efficiency if compared to diesel locomotive engines particularly when at idle speed [4, $5]$.

At «Bryansk Machine-Building Plant» Management Company JSC, the TEM18G shunting gas-turbine locomotive was designed and built on the basis of the TEM18 shunting locomotive. CNG ignited with diesel fuel is employed as fuel in TEM18G. LNG reserve under pressure of up to $20 \mathrm{MPa}$ is kept in stock in the ramp composed of 17 cylinders, each $200 \mathrm{dm}^{3}$ in capacity. Starting from the $4^{\text {th }}$ control notches, during operation under load, automatic CNG supply is launched. Amount of substitution of diesel fuel with CNG attained 45-50\%. Moreover, marked decline in the air emissions of harmful substances was noted: nitrogen oxides by $96 \%$; hydrocarbons by $95 \%[6,7]$.

Engineering and installation of an electronic fuel feed control system and maintenance of optimum temperature of the cylinders of diesel locomotives are one of the primarily important areas for improvement of the gas-turbine locomotives.

We are currently working actively on the development of a flow diagram of integrated system of automatic speed control of the diesel engine shaft and engine coolant temperature [6]. These systems employ electronic crankshaft speed controllers and coolant temperature controllers based on the state-of-the-art microprocessor technology.

Input data inclusive of information on evaluation of the potential variation range of principal parameters of the monitored unit is provided for the development of automatic control systems.

Variation ranges of principal parameters of the diesel locomotive running on natural gas is broader than ranges noted during operation on diesel fuel due to a wider range of thermophysical properties of the natural gas components.

During the process of conversion of series-production diesel locomotive engines particularly concerning use of natural gas as motor fuel, economically organization of the process of ignition with igniting fuel charge is most effective (gas-liquid engine), which apart from variation of environmental behavior of the live engine causes changes of conditions of the heat exchange processes in the combustion chamber. Such an approach 
demands the minimum amount of modification. However, the more detailed study of gasliquid processes is required regardless of the fact that these processes help to assess operation capacity of engine design.

Diesel fuel, which is used as an ignition fuel charge, demonstrates relatively stable behavior though during supply of gas fuel for intensification of operation the liquid to gas ratio alters materially along with the changing parameters of integrated fuel inclusive of the lower heating value, burning temperature, etc. Furthermore, natural gas features the broad range of composition changes and, as a consequence, of its properties [8, 9].

Summing up, the ranges of variation of key parameters of the monitored unit when running on diesel fuel and natural gas must be assessed for engineering of the integrated system of automatic speed control of the diesel engine shaft and coolant temperature.

Key gaseous fuel specifications established according to GOST 5542-87 are listed in Table 1.

Table 1. Key Gaseous Fuel Specifications (Natural Gas as per GOST 5542-87).

\begin{tabular}{|c|c|}
\hline Index & Value \\
\hline Lower heating value at $20^{\circ} \mathrm{C}$ and $0.1013 \mathrm{MPa} . \mathrm{MJ} / \mathrm{m}^{3}\left(\mathrm{kcal} / \mathrm{m}^{3}\right)$, not below & $31.8(7600)$ \\
\hline Density at $20^{\circ} \mathrm{C}$ and $0.1013 \mathrm{MPa} . \mathrm{kgm}{ }^{3}$ & $0.676 \ldots 0.83$ \\
\hline Mass concentration of hydrogen sulphide. $\mathrm{g} / \mathrm{m}$, not above & 0.02 \\
\hline Mass concentration of mercaptan sulphur, $\mathrm{g} / \mathrm{kg}$, not above & 0.036 \\
\hline Oxygen volume ratio. $\%$. not above & 1.0 \\
\hline Mass of mechanical impurities in $1 \mathrm{~m}^{3}, \mathrm{~g}$, not above & 0.001 \\
\hline Ignition point, $\mathrm{K}\left({ }^{\circ} \mathrm{C}\right)$ & $900 \ldots 1100$ \\
$(627 \ldots 827)$ \\
\hline Inflammability limits (for methane), \% \\
\hline Lower & 5 \\
\hline Upper & 15 \\
\hline
\end{tabular}

Thermophysical properties of a mixture of gases forming part of natural gas depend on the content of a particular component including methane. GOSTe does not set in an explicit form content of individual components of natural gas; it just specifies the minimum lower heating value and density.

Natural gases produced at the gas, gas condensate and oil fields belong to one of the numerous types of chemical compounds and are basically a mixture of saturated hydrocarbons, predominantly alkanes $\left(\mathrm{C}_{n} \mathrm{H}_{2 n+2}\right)$. It is specified that methane $\mathrm{CH}_{4}$ content of which achieves $99 \%$ by volume is the major component of natural gas.

Table 2 contains data on actual composition of natural gases at the certain fields in Russia [10].

Table 2. Gas Fractional Analysis (\%(vol.)) and Density at the Principal Fields of Russia.

\begin{tabular}{|c|c|c|c|c|c|c|c|c|c|c|}
\hline \multirow[b]{2}{*}{ Item } & \multirow[b]{2}{*}{ Field } & \multicolumn{5}{|c|}{ Hydrocarbons } & \multicolumn{3}{|c|}{ Other Components } & \multirow{2}{*}{$\begin{array}{c}\text { Density } \\
\text { at } 20^{\circ} \mathrm{C} \\
\mathrm{kg} / \mathrm{m}^{3}-\end{array}$} \\
\hline & & $\mathrm{CH}_{4}$ & $\mathrm{C}_{2} \mathrm{H}_{6}$ & $\mathrm{C}_{3} \mathrm{H}_{8}$ & $\mathrm{C}_{4} \mathrm{H}_{10}$ & $\begin{array}{c}\mathrm{C}_{5} \mathrm{H}_{12} \\
\text { and above }\end{array}$ & $\mathrm{H}_{2} \mathrm{~S}$ & $\mathrm{CO}_{2}$ & $\begin{array}{l}\mathrm{N}_{2}+ \\
\text { rare }\end{array}$ & \\
\hline 1 & Urengoy & 99.05 & 0.06 & 0.01 & - & - & - & 0.08 & 0.80 & 0.6733 \\
\hline 2 & Yamburg & 95.20 & 0.04 & 0.06 & 0.001 & 0.10 & - & 0.30 & 4.50 & 0.6956 \\
\hline 3 & Zapolyarnoye & 98.80 & 0.07 & 0.01 & 0.004 & 0.01 & - & 0.116 & 0.99 & 0.6756 \\
\hline 4 & Medvezhye & 98.56 & 0.17 & 0.01 & 0.02 & 0.02 & - & 0.22 & 1.00 & 0.6775 \\
\hline 5 & Bovansikovskoye & 95.96 & 3.32 & 0.06 & 0.05 & - & - & 0.06 & 0.55 & 0.6927 \\
\hline
\end{tabular}




\begin{tabular}{|c|l|c|c|c|c|c|c|c|c|c|}
\hline 6 & Middle Yamal & 78.97 & 4.53 & 2.34 & 1.02 & 0.27 & - & 1.02 & 11.84 & 0.8194 \\
\hline 7 & Orenburg & 83.68 & 3.81 & 1.53 & 0.84 & 1.58 & 1.75 & 0.57 & 6.23 & 0.8167 \\
\hline 8 & Vuktylskoye & 75.1 & 8.9 & 3.6 & 1.5 & 6.4 & - & 0.1 & 4.4 & 0.8130 \\
\hline 9 & Layavozhskoye & 79.71 & 3.53 & 1.17 & 0.49 & 0.33 & & 2.19 & 12.91 & 0.8126 \\
\hline 10 & Middle Vilyui & 90.6 & 4.9 & 1.7 & 0.6 & 1.4 & - & 0.5 & 0.3 & 0.7621 \\
\hline
\end{tabular}

Density at $20^{\circ} \mathrm{C}$ was calculated by additivity based on the density of individual components listed in Appendix 2 to GOST 22667-82 by method of conversion of them to $\mathrm{Kg} / \mathrm{m}^{3}$ through multiplication by density for the air equal to $1.2047 \mathrm{\kappa g} / \mathrm{m}^{3}$.

From Table 2 we can observe that $\mathrm{CH} 4$ methane fraction in composition of natural gas may vary over a wide range, namely, from 75 to $99 \%$.

Alongside with methane, composition of natural gases includes even heavier hydrocarbons: ethane, propane, butane, pentane isobutane, iso- and neoneptane, hexanes, heptanes, as well as such chemical elements as hydrogen sulphide, mercaptan sulphur. Lighter mercaptans, namely, methanethiol and ethanethiol are found in the gaseous hydrocarbon mixture.

Properties of individual substances most frequently found in natural gas are listed in Table 3.

Table 3. Properties of Gases Found in Natual Gas

(GOST 31369-2008 and GOST 8-662-2009).

\begin{tabular}{|c|c|c|c|c|c|c|}
\hline Item & Gas & $\begin{array}{c}\text { Chemical } \\
\text { Formula }\end{array}$ & $\begin{array}{c}\text { Molar Mass } \mu, \\
\mathrm{g} / \text { mole }\end{array}$ & $\begin{array}{c}\text { Density } \rho, \\
\mathrm{Kg} / \mathrm{m}^{3}\end{array}$ & $\begin{array}{c}\text { Boiling } \\
\text { Point, }{ }^{\circ} \mathrm{C}\end{array}$ & $\begin{array}{c}\mathrm{Hu}, \\
\mathrm{MJ} / \mathrm{m}^{3}\end{array}$ \\
\hline 1 & Methane & $\mathrm{CH}_{4}$ & 16.043 & 0.7168 & -161.6 & 35.88 \\
\hline 2 & Ethane & $\mathrm{C}_{2} \mathrm{H}_{6}$ & 30.070 & 1.342 & -88.6 & 64.36 \\
\hline 3 & Propane & $\mathrm{C}_{3} \mathrm{H}_{8}$ & 44.097 & 1.967 & -42.09 & 93.18 \\
\hline 4 & N-butane & $\mathrm{C}_{4} \mathrm{H}_{10}$ & 58.123 & 2.593 & -0.5 & 123.57 \\
\hline 5 & Pentane & $\mathrm{C}_{5} \mathrm{H}_{12}$ & 72.15 & 3.219 & -129.72 & 156.63 \\
\hline 6 & Hydrogen & $\mathrm{H}_{2}$ & 2.0159 & 0.0899 & -252.7 & 10.79 \\
\hline 7 & $\begin{array}{c}\text { Hydrogen } \\
\text { sulphide }\end{array}$ & $\mathrm{H}_{2} \mathrm{~S}$ & 34.082 & 1.5206 & -60.28 & 23.37 \\
\hline 8 & Helium & $\mathrm{He}_{2}$ & 4.0026 & 0.1785 & -267.8 & - \\
\hline 9 & Nitrogen & $\mathrm{N}_{2}$ & 28.013 & 1.251 & -195.8 & - \\
\hline
\end{tabular}

The quoted data pertains to standard conditions $\left(25^{\circ} \mathrm{C}, 100 \mathrm{kPa}\right)$, unless otherwise specified.

From Table 3 it follows that there is an appreciable difference in the lower heating value $\mathrm{H}_{\mathrm{u}}$ of various gases contained in natural gas. For instance, pentane has the lower heating value $\mathrm{H}_{\mathrm{u}}=156.63 \mathrm{MJ} / \mathrm{m}^{3}$, while methane $\mathrm{H}_{\mathrm{u}}=35.88 \mathrm{MJ} / \mathrm{m}^{3}$.

The lower heating value of dry gas is determined by the following dependence [11]:

$\mathrm{H}_{\mathrm{u}}=126 \cdot \mathrm{CO}+108 \cdot \mathrm{H}_{2}+238 \cdot \mathrm{H}_{2} \mathrm{~S}+358 \cdot \mathrm{CH}_{4}+636 \cdot \mathrm{C} 2 \mathrm{H} 6+600 \cdot \mathrm{C} 2 \mathrm{H} 4+910 \cdot \mathrm{C} 3 \mathrm{H} 8+$ $882 \cdot \mathrm{C} 3 \mathrm{He}+1187 \cdot \mathrm{C} 4 \mathrm{H} 10++1462 \cdot \mathrm{C} 5 \mathrm{H} 12\left[\mathrm{KJ} / \mathrm{m}^{3}\right]$,

where $\mathrm{CO}, \mathrm{H}_{2}, \mathrm{H}_{2} \mathrm{~S}, \mathrm{CH}_{4}$ are volume fractions of respective simple gases, $\%$.

The lower heating value of natural gases with the maximum and with the minimum content of methane was computed based on the quoted dependence.

Natural gas from the Urengoy Field has the lower heating value $\mathrm{H}_{\mathrm{u}}=35.46 \mathrm{MJ} / \mathrm{m}^{3}$, while natural gas from the Vuktylskoye Field has $\mathrm{H}_{\mathrm{u}}=46.96 \mathrm{MJ} / \mathrm{m}^{3}$, in other words, 32.4 $\%$ higher than the lower heating value noted at the Urengoy Field. 
Taking into account that air contains $21 \%$ of oxygen, amount of air theoretically needed for the complete combustion of $1 \mathrm{~m}^{3}$ of fuel [11]:

$\mathrm{L}_{0}=0.0238 \cdot\left[\mathrm{CO}+\mathrm{H}_{2}+3 \mathrm{H}_{2} \mathrm{~S}+2 \Sigma(n+0.25 m) \cdot \mathrm{CnH} m\right],\left[\mathrm{m}^{3} / \mathrm{m}^{3}\right]$.

or not including hydrogen, carbon monoxide and hydrogen sulphide:

$\mathrm{L}_{0}=0.0476\left(2 \cdot \mathrm{CH}_{4}+3.5 \cdot \mathrm{C} 2 \mathrm{H} 6+5 \cdot \mathrm{C} 3 \mathrm{H} 8+6.5 \cdot \mathrm{C} 4 \mathrm{H} 10+8 \cdot \mathrm{C} 5 \mathrm{H} 12\right),\left[\mathrm{m}^{3} / \mathrm{m}^{3}\right]$.

Included in Table 4 are results of calculation of stoichiometric air $1 \mathrm{~m}^{3}$ or $1 \mathrm{~kg}$ of basic hydrocarbons found in natural gas.

Table 4. Calculation of Theoretical Air Consumption (Stoichiometric Coefficients) Required for the Complete Combustion of Basic Hydrocarbons.

\begin{tabular}{|c|c|c|c|c|c|}
\hline Gas & Methane & Ethane & Propane & Butane & Pentane \\
\hline $\mathrm{L}_{0}, \mathrm{~m}^{3} / \mathrm{m}^{3}$ & 9.52 & 16.66 & 23.8 & 30.94 & 38.08 \\
\hline $\mathrm{L} 0, \mathrm{Kg} / \mathrm{kg}$ & 17.17 & 15.89 & 15.36 & 14.8 & 14.24 \\
\hline
\end{tabular}

As far as natural gas of the Urengoy Field is concerned, then stoichiometric air required for the complete combustion of $1 \mathrm{~m}^{3}$ of fuel $\mathrm{L}_{0}=9.44, \mathrm{~m}^{3} / \mathrm{m}^{3}$ or weight $\mathrm{L}_{0}=16.89 \mathrm{~kg} / \mathrm{kg}$, while for air of the Vuktylskoye Field $\mathrm{L}_{0}=12.39, \mathrm{~m}^{3} / \mathrm{m}^{3}$ or weight $\mathrm{L}_{0}=15.26 \mathrm{rg} / \mathrm{kg}$. As far as natural gas from the Vuktylskoye Field as related to natural gas is concerned, then volume and weighted stoichiometric coefficients differ, namely: volume coefficient is $31.2 \%$ greater, and weighted coefficient is $9.7 \%$ less.

As part of the study of combustion processes, calculation data and outcomes of experiments shall be processed and further presented against certain criteria for instance such parameters as combustion rate, steady-state combustion range depending on excess air ratio $\alpha$, which is defined as the ratio between actual air flow rate in the device to product of the theoretical air consumption required for combustion of a fuel unit (in $\mathrm{kg} \mathrm{or} \mathrm{m}^{3}$ ) and fuel consumption.

Taking into consideration mentioned above and the fact that composition and stoichiometric coefficients of natural gas produced at the different fields differ markedly, test data should be processed with due regard to the actual composition of natural gas and fractions of diesel fuel and natural gas in motor fuel.

As is customary, test data processing and reporting of key parameters of heat engines such as engine power, specific fuel consumption, environmental behavior, etc., shall be carried out with due regard for environmental parameters. Such engine performance as engine speed shall be checked during block test. Air pressure and temperature measured during engine test will vary depending on the season and test location. Therefore, data on engine power and specific fuel consumption acquired in the course of engine test may be above or below values specified in the basic specifications of the engine. In order to appraise conformity of parameters to the engine basic specifications it is essential to reduce them to air standard conditions. The air standard conditions are as follows: barometric air pressure $-760 \mathrm{~mm}$ of mercury $\left(1.033 \mathrm{~kg} / \mathrm{cm}^{2}, 0.1033 \mathrm{MPa}\right)$, temperature $-15^{\circ} \mathrm{C}(288 \mathrm{~K})$.

When operating diesel locomotives on liquid-gas fuel, the so-termed standard lower heating value of diesel fuel and natural gas should be taken into account in addition to atmospheric conditions.

The standard lower heating value of natural gas may be conventionally assigned proceeding from some regulatory and technical data on natural gas.

The volume ratio of basic components of natural gas as per technical specification TU 51-03-03-85 (information source: «Cryogenmash» PJSC): methane 92\% $\pm 6 \%$, ethane 4\% $\pm 3 \%$, propane and heavier hydrocarbons $2.5 \% \pm 2.5 \%$, nitrogen $1.8 . \% \pm 1.5 \%$. The lower heating value $\mathrm{H}_{\mathrm{u}}=39.1 \mathrm{MJ} / \mathrm{m}^{3}$ or $11289 \mathrm{kcal} / \mathrm{kg}(47.3 \mathrm{MJ} / \mathrm{kg})$.

The lower heating value of fuel has direct impact on the diesel unit horsepower efficiency. For this very reason this index serves as the main quality factor of any diesel fuel (DF) as its increment leads to decrease in fuel consumption. 
Limits of values of the lower heating value of DF established in accordance with the Russian and international standards fall within the range of $39.2 \ldots 43.3 \mathrm{MJ} / \mathrm{kg}$. This index may be determined empirically under laboratory conditions. Typically, technical publications point to the lower heating value of $\mathrm{DF} \mathrm{H}_{\mathrm{u}}=42.2 \mathrm{MJ} / \mathrm{kg}$, and therefore this value may be conventionally taken as the standard value.

In the case of shared use of diesel fuel and natural gas, the standard lower heating value should be calculated according to the formula

$$
\mathrm{H}_{\mathrm{ust}}=\left(\mathrm{G}_{\mathrm{DF}} \cdot 42.2+\mathrm{G}_{\mathrm{NG}} \cdot 47.3\right) /\left(\mathrm{G}_{\mathrm{DF}}+\mathrm{G}_{\mathrm{NG}}\right), \mathrm{MJ} / \mathrm{kg},
$$

where $\mathrm{G}_{\mathrm{DF}}-\mathrm{DF}$ consumption in $\mathrm{kg}$;

42.2 - the lower heating value of $\mathrm{DF}, \mathrm{MJ} / \mathrm{kg}$;

$\mathrm{G}_{\mathrm{NG}}$ - natural gas consumption in $\mathrm{kg}$;

42.2 - the lower heating value of natural gas, $\mathrm{MJ} / \mathrm{kg}$.

In the case of shared use of diesel fuel and natural gas, the actual lower heating value $\mathrm{H}_{\text {uact }}$ must be calculated in a similar way like the standard value except that standard values of the lower heating value must be substituted with the actual values.

When the so called standard lower heating value of diesel fuel and natural gas is considered in addition to atmospheric conditions, the values of engine power and specific fuel consumption obtained during diesel locomotive test must be divided by the actual lower heating value $\mathrm{H}_{\text {uact }}$ and then multiplied by the standard computed according to Equation (1).

With reference to the above-cited desktop study data, a methodology of calculation of heat released during combustion of composite propellant was devised with due regard for blend composition of natural gas required to obtain the optimum performance data of diesel locomotive engines. The total amount of heat fed during combustion of blend composite propellant should be computed with due regard to impact of methane concentration in natural gas of various fields and according to blend composition ratio $\mathrm{K}_{0}$ with the empirically estimated value based on the test certificate processing data $[12,13]$.

An equation of the relative definition of amount of heat fed during combustion of composite propellant with provision for the blend composition ratio $\mathrm{K}_{0}$ shall take on the following form:

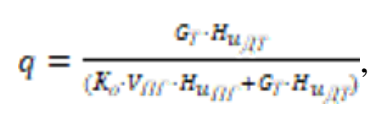

where $K_{0}=f\left(H_{u}\right)$ - blend composition ratio;

$G_{T}$ - fuel consumption by the diesel locomotive, $\mathrm{m}^{3} /$ hour;

$H_{u_{U T}}$ - lower calorific value of diesel fuel, $\mathrm{MJ} / \mathrm{m}^{3}$;

$H_{u_{f i}}$ - lower calorific value of natural gas, $\mathrm{MJ} / \mathrm{m}^{3}$;

$V_{I I}$ - corrected consumption of natural gas per hour, $\mathrm{m}^{3} /$ hour.

Blend composition ratio $\mathrm{K}_{0}$ means a non-dimensional value, which points at change of calorific efficiency of natural gas depending on the field from which it was delivered. 


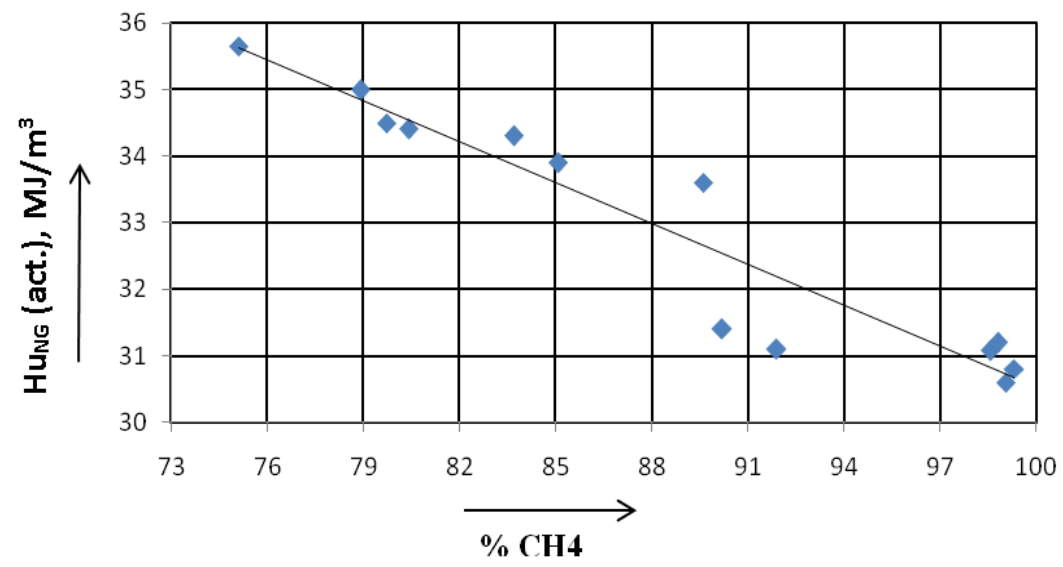

Fig. 1. Relationship of Actual Natural Gas Calorific Value $\mathrm{H}_{\mathrm{uNG}(\text { act) }}$ to $\mathrm{CH}_{4}$ Methane Content.

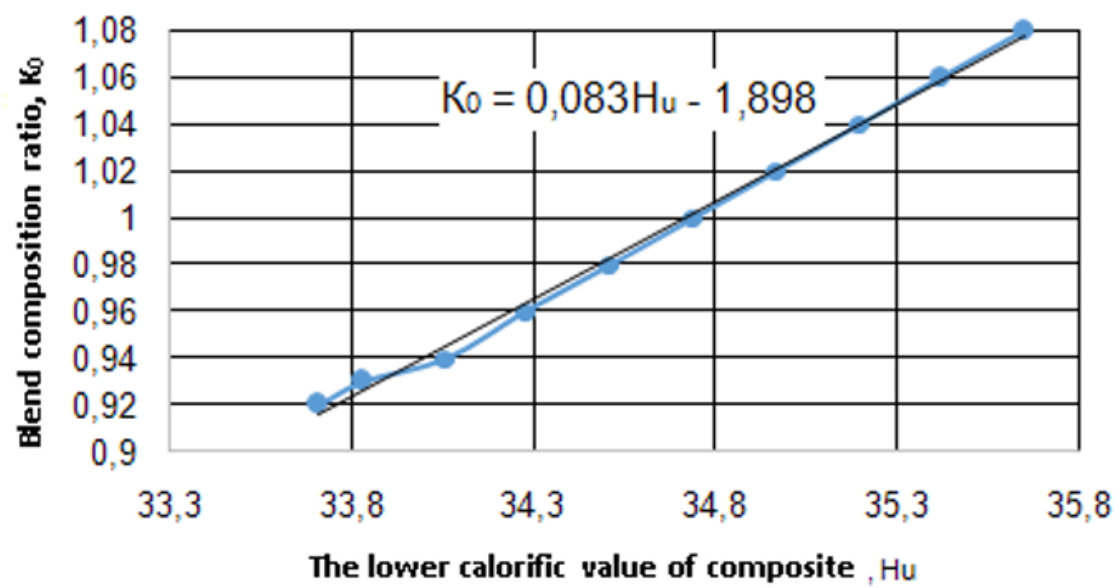

Fig. 2. Relationship of Blend Composition Ratio $\mathrm{K}_{0}$ to the Lower Heating Value of Composite Propellant Hu.

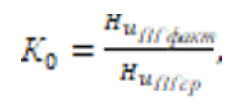

where, $H_{u_{S J S \text { dax }}}$ - actual heating value of natural gas (to be shown in the field certificate), $\mathrm{MJ} / \mathrm{m}^{3}$;

$H_{u_{S S C Q}}$ - average sampling heating value of natural gas by the fields, $\mathrm{MJ} / \mathrm{m}^{3}$.

Upon completion of processing of test certificates obtained from the various natural gas

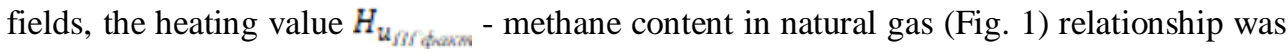
developed. As the range of methane content in natural gas equals $75-99 \%$, then the blend composition ratio must range from $0.92-1.08$ to maintain its heating value equal to $35.8 \mathrm{M}$ $\mathrm{J} / \mathrm{m}^{3}$.

It seems advisable to use this range of $\mathrm{K}_{0}$ ratio for setting diesel locomotive engines running on composite propellant, which makes it possible to ensure optimum values of the specific efficient consumption of diesel fuel. Should methane content in mole fractions in composite propellant be higher, then the heating value of this mix shall decline, which may necessitate increase of input fuel and adjustment of controlling trends with the utilization of automated control systems (ACS). 
Summing up what has been said, is it expedient to adjust fuel consumption providing for the actual heating value. As no average constant value was defined for $H_{u_{\delta S \delta} \text { daxm }}$, then, for example, average sampling value $H_{u_{\delta S C Q}}=33.01 \mathrm{MJ} / \mathrm{m}^{3}$, shall change depending on the blend composition of natural gas. In order to maintain the engine power rating of diesel locomotive when feeding natural gas, its injection rate must be equivalent to the heating value of substituted diesel fuel. Keeping in mind the difference between volumetric calorific values of both types of fuel $\left(H_{u_{\mathrm{IT}}}=33,06 \mathrm{M} Д ж / \mathrm{m}^{3}\right.$ and $H_{u_{\Pi \Gamma}}=35,8 \mathrm{MДж} / \mathrm{M}^{3}$ ), we must fulfill the following condition:

$$
\Delta V_{\mathrm{T}} H_{u_{\mathrm{IT}}}=\Delta V_{\Pi \Gamma} H_{u_{\Pi \Gamma}}
$$

where $\Delta V_{T}$ and $\Delta V_{\Pi \Gamma}$ - volumetric feed of diesel fuel and natural gas per one cycle, $\mathrm{m}^{3}$, respectively;

$H_{u_{\mathrm{IT}}}$ and $H_{u_{\Pi \Gamma}}$ - lower heating value of diesel fuel and natural gas, $\mathrm{MJ} / \mathrm{m}^{3}$, respectively.

Consequently, based on the lower heating value we shall define the required amount of natural gas and diesel fuel to be fed.

From condition (4) we shall find the volume of natural gas per one engine operating cycle subject to the assumption of equal efficiency of combustion of both types of fuel:

$$
\Delta V_{I I T}=\Delta V_{T} \frac{H_{u / T}}{H_{u_{S S}}} \text {. }
$$

$\Delta \mathrm{V}_{\mathrm{NG}}$ of each diesel locomotive directly depends on the fuel injection rate. The maximum power of diesel locomotive $6 \mathrm{ChN} 31 / 36$ is aligned with the injection rate of diesel fuel $q_{u}=1.52 \mathrm{~g} / \mathrm{cycle}$, which achieves the volumetric supply of $\Delta V_{T}=1.81 \cdot 10^{-6} \mathrm{~m}^{3}$ with the specific fuel weight $\gamma=840 \mathrm{Kg} / \mathrm{m}^{3}$. With due regard for accepted changes of mixtures of diesel fuel with natural gas under the additive law, we shall compute the required fuel volume $\Delta V_{T}$, fed to cylinder per one engine operating cycle (Table 5).

By varying the fuel composition through changes of natural gas content in the range of 1 to $90 \%$ of the total amount of fed fuel, we shall calculate parameters of composite propellant supply adjusted for the blend composition ratio $\mathrm{K}_{0}$ of natural gas (Fig. 2). It is apparent from Table 1 that when diesel fuel is substituted with natural gas, the heating value of composite propellant increases, and, accordingly, actual volumetric fuel feed of natural gas must be decreased approximately by $10 \%$. The reason of it is discrepancy in the calorific power of diesel fuel and natural gas.

Table 5. Parameters of Injection of Composite Propellant on the Rated Power Setting of Diesel

\begin{tabular}{|c|c|c|c|c|c|c|c|c|c|c|c|}
\hline \multirow[b]{2}{*}{ Parameter } & \multicolumn{11}{|c|}{ Composite Propellant Formulation } \\
\hline & $\overrightarrow{0}$ & 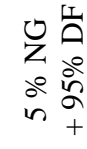 & $\begin{array}{ll}0 & 1 \\
z & 0 \\
0 & 8 \\
0 & 8 \\
0 & +\end{array}$ & \begin{tabular}{ll}
0 & \multicolumn{1}{c}{} \\
$Z$ & 0 \\
0 & 0 \\
0 & $\infty$ \\
0 & +
\end{tabular} & $\begin{array}{ll}0 & 1 \\
z & 0 \\
0 & 0 \\
0 & 0 \\
0 & +\end{array}$ & $\begin{array}{l}0 \\
Z \\
0 \\
0 \\
0 \\
0 \\
0 \\
0 \\
+\end{array}$ & $\begin{array}{l}0 \\
z \\
0 \\
0 \\
0 \\
0 \\
0 \\
n\end{array}$ & $\begin{array}{l}0 \\
Z \\
0 \\
0 \\
0 \\
0 \\
0 \\
0 \\
+\end{array}$ & \begin{tabular}{ll}
0 & \multicolumn{1}{c}{} \\
$z$ & 0 \\
0 & 0 \\
0 & 0 \\
$r$ & +
\end{tabular} & $\begin{array}{ll}0 & 1 \\
Z & 0 \\
0 & 0 \\
0 & 0 \\
\infty & + \\
\infty & +\end{array}$ & $\begin{array}{l}0 \\
2 \\
0 \\
0 \\
0 \\
8 \\
8\end{array}$ \\
\hline $\begin{array}{l}\text { Lower heating } \\
\text { value } H_{u}, \\
\mathrm{MJ} / \mathrm{m}^{3}\end{array}$ & 33.06 & 33.71 & 33.83 & 34.06 & 34.28 & 34.51 & 34.74 & 34.97 & 35.20 & 35.42 & 35.65 \\
\hline Ratio $K_{0}$ & - & 0.92 & 0.93 & 0.94 & 0.96 & 0.98 & 1.0 & 1.02 & 1.04 & 1.06 & 1.08 \\
\hline
\end{tabular}
Locomotive $6 \mathrm{ChN} 1 / 36$. 


\begin{tabular}{|c|c|c|c|c|c|c|c|c|c|c|c|}
\hline $\begin{array}{l}H_{u_{\mathrm{IT}}} / H_{u_{\mathrm{CME}}} \\
\text { relationship }\end{array}$ & & 0.981 & 0.977 & 0.971 & 0.964 & 0.958 & 0.952 & 0.945 & 0.939 & 0.933 & 0.927 \\
\hline \begin{tabular}{|l} 
Fuel volume \\
per one cycle \\
Vf. $\left(\mathrm{m}^{3} \cdot 10^{6}\right)$
\end{tabular} & 1.81 & 1.72 & 1.629 & 1.448 & 1.267 & 1.086 & 0.905 & 0.724 & 0.543 & 0.362 & 0.181 \\
\hline $\begin{array}{l}\text { Gas volume } \\
\text { per one cycle } \\
\mathrm{V}_{\mathrm{NG}},\left(\mathrm{m}^{3} \cdot 10^{6}\right)\end{array}$ & - & 88.4 & 176.8 & 353.6 & 530.4 & 707.2 & 884 & 1060.8 & 1237.6 & 1414.4 & 1591.2 \\
\hline $\begin{array}{l}\text { Fuel mass per } \\
\text { one cycle } \mathrm{q}_{\Perp}, \mathrm{g}\end{array}$ & 1.52 & 1.44 & 1.37 & 1.22 & 1.06 & 0.91 & 0.76 & 0.61 & 0.46 & 0.31 & 0.15 \\
\hline
\end{tabular}

The zero-dimensional thermodynamic model of calculation of operating cycle during operation of the diesel locomotive with addition of natural gas to diesel fuel was applied for the locomotive-type diesel engine. Calculation of the operating cycle, indicator and performance values of $6 \mathrm{CHN} 31 / 36$ diesel was performed adjusted for $\mathrm{K}_{0}$ ratio according to the proposed model.

In this case, specific efficient consumption rate of diesel fuel, in $\mathrm{g} / \mathrm{kW} \cdot \mathrm{h}$ :

$$
b_{e}=3600 \cdot \frac{q}{\eta_{e} \cdot H_{u / g} \xi},
$$

where $\xi$ - combustion efficiency ratio; $\xi=\psi \cdot \delta$

$\psi$ and $\delta$ - heat availability factor and coefficient of heat emission.

\section{Practical relevance}

As it appears form the graph (Fig. 3), increase of fraction of natural gas in diesel fuel leads to growth of the mixture heating value as evidenced by the $\mathrm{K}_{0}$ ratio, improvement of specific parameters of the diesel engine. Specific efficient consumption of diesel fuel goes down, when under low and average loads typical of the shunting diesel locomotives $\left(2^{\text {nd }}-5^{\text {th }}\right.$ control notches) reduction makes $8-12 \%$, and in the nominal conditions $-5 \%$.

As natural gas contains a significant quantity of carbons, then level of emissions of toxic substances directly depends on the total fuel consumption.

Further, along with the growing fraction of natural gas in diesel fuel we observe increment of effective power of diesel locomotive for all control notches. The largest gain value matches with the rated operating condition of diesel locomotive and comes up to $4 \%$ $[14,15]$.

The optimum design values of performance indicators of diesel locomotive when diesel fuel is substituted with natural gas were observed with the blend composition ratio $\mathrm{K}_{0}=1.08$ for natural gas. 


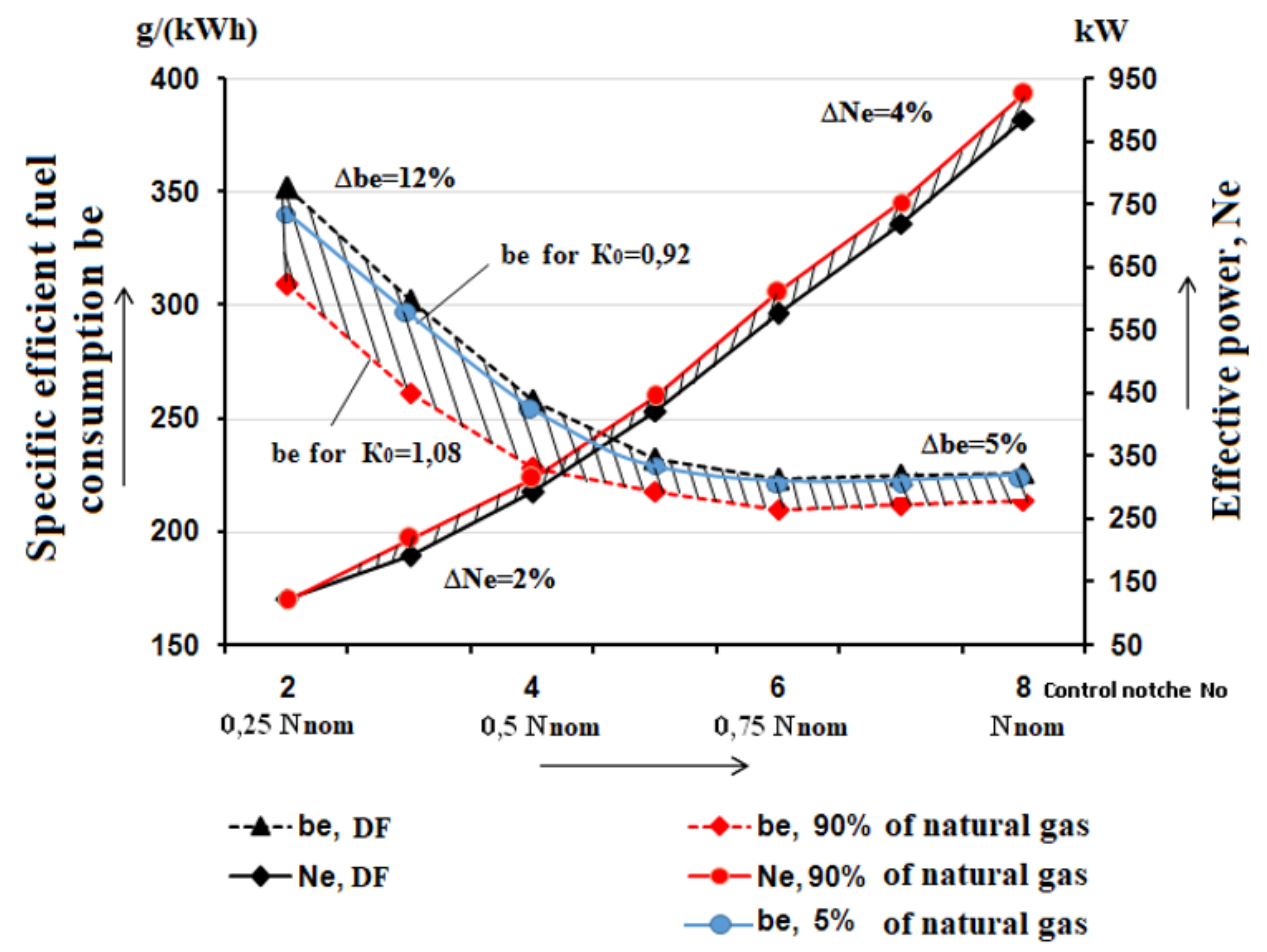

Fig. 3. 6ChN 31/36 Diesel Performance Data for Operation on Composite Propellant Depending on Operating Conditions and Adjusted for Blend Composition Ratio $\mathrm{K}_{0}$.

\section{Conclusion}

The findings of the performed researches testify that under otherwise equal conditions and with due regard for the blend composition ratio $\mathrm{K}_{0}$, power ascension will occur, but in compliance with the requirements specified in Diesel Locomotive Operating Rules and Rheostat test Manual, required power must be endured. As a consequence, in such cases fuel consumption must be reduced in order to keep up with the rated power ascension.

\section{References}

1. D.Ya. Nossyrev, L.S. Kurmanova, S.A. Petukhov, et al., Ecology and Industry of Russia, 23(2), 19-23 (2019) DOI: 10.18412/1816-0395-2019-02-19-23

2. Ye.A. Lazarev, V.S. Murzin, V.Ye. Lazarev, et al., Mechanical Engineering, 13(1), 3643 (2013)

3. N.G. Kirillov, A.N. Lazarev, Engine Manufacturing, 1, 26-33 (2010)

4. N.G. Kirillov, A.N. Lazarev, Engine Manufacturing, 2, 27-33 (2010)

5. G.A. Fofanov, Railroads of the World, 7, 43-48 (2006)

6. X. Kasymkanova, G. Dzhangulova, R. Bekseitova, et al., Series of Geology and Technical Sciences, 5 (431), 37-46 (2018) DOI: 10.32014/2018.2518-170X.33

7. G. Zh. Zholtaev, K.O. Iskaziev, B.K. Abayıldanov, News of the National Academy of Sciences of the Republic of Kazakhstan. Series of Geology and Technical Sciences, 6 (432), 163-171 (2018) DOI: 10.32014/2018.2518-170X.22 
8. S. Park, Y. Kim, S. Woo, et al., Applied Thermal Engineering, 123, 917-928 (2017)

9. V.G. Kamaltdinov, Ye.V. Abeliovitch, Mechanical Engineering, 23 (123), 46-53 (2008)

10. V.G. Kucherov, A.B. Zolotukhin, V.V. Bessel, et al., Gas Industry, S716, 8-12 (2014)

11. V.A. Likhanov, O.P. Lopatin, Tractors and Agricultural Machinery, 1, 11-13 (2010)

12. D. Ya. Nossyrev, A. Yu. Balakin, et al., Povolzhye Transport Newsletter, 2(56), 33-38 (2016)

13. L.S. Kurmanova, Povolzhye Transport Newsletter, 6(72), 108-114 (2018)

14. L.S. Kurmanova, Trans-Siberian Buletin, 3(31), 20-27 (2017)

15. A.Yu. Balakin, D.Ya. Nossyrev, et al., Dvigatel (Engine), 48-49 (2018) 